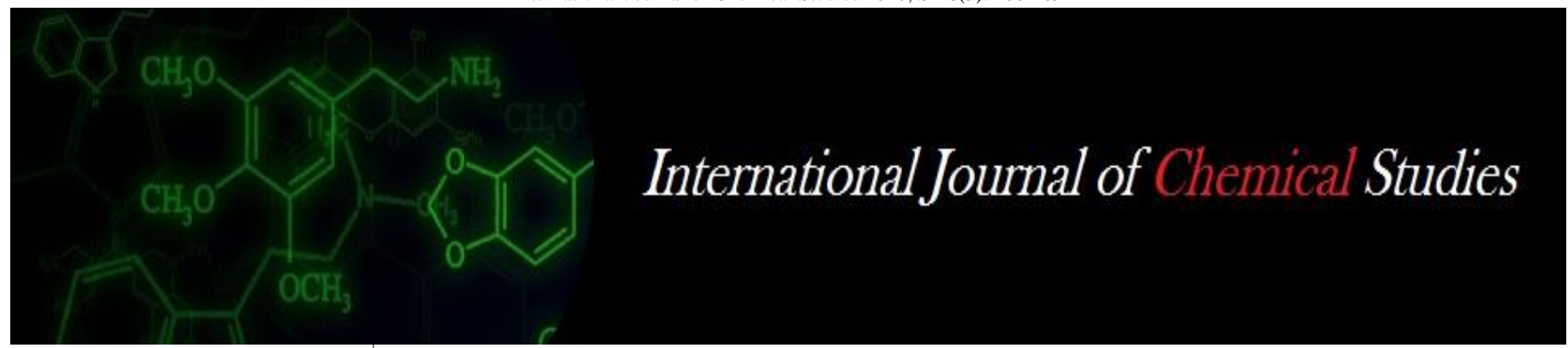

P-ISSN: 2349-8528

E-ISSN: 2321-4902

www.chemijournal.com

IJCS 2020; SP-8(5): 166-169

(C) 2020 IJCS

Received: 02-07-2020

Accepted: 05-08-2020

Niraj Pali

Institute of Agriculture Sciences,

SAGE University, Indore,

Madhya Pradesh, India

Chandra Kant Sharma

Institute of Agriculture Sciences,

SAGE University, Indore,

Madhya Pradesh, India

\section{Nursery management for horticulture crops}

\author{
Niraj Pali and Chandra Kant Sharma
}

DOI: https://doi.org/10.22271/chemi.2020.v8.i5d.10525

\begin{abstract}
India is featured with diverse and remarkably vast form of diversity among agro-climatic zone which gives a pave for the production of different types of horticultural crops like vegetables, plantation crops, ornamentals, flowers and so on. As agriculture is the backbone of Indian economy, it plays a vital role in providing livelihood for more than $70 \%$ of labour force. Horticulture is the branch of agriculture science which involves many areas of study. When considering the present scenario, the providence of various horticultural crops has been made possible by the establishment of nursery. The prime objective of a nursery is to provide the planting material at best quality for adoption and establishment in new environment. The present study is based on the nursery management in horticultural crops. This review article covers all the important aspects practised in nursery management like potting of seedling, manuring and irrigation, plant protection measures, weed control, packaging and marketing of nursery plants.
\end{abstract}

Keywords: Nursery, management, horticulture crops, remarkably

\section{Introduction}

India is surrounded by a remarkably vast area of diversity among agro-climatic zones which allows the growing of a variety of fruits crops, vegetable crops, medicinal crops, ornamental crops and so on. As agriculture sector is the backbone of Indian economy the overall population depends upon the agriculture food. Growing population demands for more food products. In the context of this, planting crops in nursery is a suitable mode to meet the demands of the population. Nursery is a place where planting material, such as seedlings, saplings, cuttings, etc., are raised, propagated and multiplied under favourable conditions for transplanting in prepared beds. The nursery ensures better germination and establishment and also ensures saving of time, area and labour and makes easy maintenance (Tripathi et al. 2010) [10].

The availability of quality and true-to-type planting material is the prerequisite of successful and remunerative ornamental crop production. Setting up of a nursery is a long-term venture, and requires planning and expertise. Production of off-season vegetable nurseries under protected structure has become a profitable business. The main purpose of raising nursery plants in protected structure is to get higher profit and disease free seedlings in off season to raise early crop in protected condition or/and open field condition (Yadav et al. 2014) ${ }^{[7]}$. In a nursery, plants are nurtured by providing them with optimum growing conditions to ensure germination. Nursery saves considerable time for the raising of the next crop. Among flower crops, majority of the annuals are propagated by seeds and require a nursery for raising the seedlings. Herbaceous perennials need nurseries for sowing of seeds and planting of cuttings for rooting and establishment. Woody perennials are grown from seeds for multiplying the rootstocks from cuttings, layers and through grafts to perpetuate the same genetic properties.

\section{Definition of Nursery}

"A nursery is a place or an establishment for raising or handling of young vegetable seedlings until they are ready for more permanent planting."

\section{Nursery and Its Importance}

Nursery is an area, where new saplings are raised and nourished until they are ready for sale or transplanting at a permanent place in a field. Raising of seedlings is a important stepfor establishing a successful nursery. Here below displays some importance of nursery
Institute of Agriculture Sciences,

SAGE University, Indore,

Madhya Pradesh, India 
- A large number of plants can be grown in a given area.

- Small and expensive hybrid seeds can be raised more effectively due to better care and management.

- High germination percentage seeds with improved seed vigour are produced.

- Due to small area of the nursery, the management cost of seedlings is low with minimum care in a better way.

- Manipulation of growing conditions for plants becomes easy.

- High yielding crops are produced with better and uniform crop growth as vigorous and healthy seedlings are selected.

- High net returns can be obtained due to sowing of offseason seeds

- Low seed rate of the seeds for better crop management.

- Easy management of insect-pest, disease and weeds.

There are a number of factors affecting the quality of transplant crops. The management of transplant crop production is quite complex and needs broad experience and knowledge (Mcavoy and Ozores Hampton. 2015) ${ }^{[4]}$ Practically, all these depends upon the horticultural practices and the factors that determines the growth rate (Oagile et al., 2016) ${ }^{[6]}$, the root to shoot ratio (Sallaku et al., 2009) ${ }^{[8]}$, the crop stand (Babaj et al., 2012) ${ }^{[2]}$ and yield capabilities (Ali. 2016) ${ }^{[1]}$ of new transplants.For good nursery management it is utmost important that the available planting material is of highest possible quality for replanting and adoption in new areas. Nursery management includes various activities like selecting suitable site for nursery establishment, analysing physiological factors, potting the seedling, manuring, irrigation, plant protection measures, weed control, packing of nursery plants, transportation facilities (Singh et al. 2017) [9] For establishment of a good nursery, it is important to manage all the pre-requisite factors that are to be undertaken during nursery establishment.

\section{Some important considerations are as follows}

Selection of site

Site is the basic requirement of a nursery. A nursery must be located in a pollution-free environment Site is a place where one can produce seedlings of plants with adequate sunlight (Singh et al. 2017) ${ }^{[9]}$ A site should be

- Near to a road

- Suitable climate neither shady nor exposed area

- Sufficient sunlight

- Good irrigation facilities

- Good soil condition

- Well transport facility

Topography of land -The land for nursery should be well fertile and free from any stones or pebbles. It should be even and plain. Moderate area is required for accommodation of sufficient number of plants. If the nursery is in hilly areas, it may be divided into levelled terraces. The land should have good air circulation system will slight slope for excess water runoff. The land should be free from nematodes and diseased hot spots (Tripathiet al. 2010) ${ }^{[10]}$

Soil: The soil must preferably be loam or sandy loam with large quantity of organic matter. The $\mathrm{pH}$ of the soil must be near neutral $(6.5-7.5)$. It must have adequate water retention capacity and aeration.
Water: The quality of water used in a nursery is important for the growth of plants. Saline and polluted water must not be used. It must be ensured that there is adequate water supply for irrigation. Besides, the nursery must be located near a water source so that there is no water scarcity at any time in the course of raising plants.

Drainage: The nursery site must have adequate drainage facility and be free from water logging. Water must not stagnate at any time.

Labour: The need of labour is very essential for any nursery. Some activities like multiplication, sale of nursery plants are laborious and costly. These cost can be reduced through mechanization and automation of some of the nursery units. Propagation and hardening structures: Various propagation structures are used for rooting the cuttings, raising the seedling and producing the grafts (Singh et al. 2010). Some polyhouses, greenhouses, small shade and net houses are used for hardening of the nursery plants. Hardening off reduces the transpiration rate of the plants by thickening the cuticle.

Transportation: The nursery site must be accessible by road. It should be near to potential markets so that the damage of seedlings due to transportation is less.

Pest and disease management: The nursery area must be protected by enclosures so as to prevent damage to the plants by stray animals.

Market availability - Various types of inputs like seeds, fertilisers, pesticides, fungicides, plant growth regulators, poly bags, agricultural implements, different type of spare parts and other miscellaneous items required in the nursery must be available in the nearby market. The nursery must be located near the city or an area from where people can purchase the plants.

\section{Types of nursery}

There are various types of nurseries. Some of them are described below:

\section{Temporary nursery}

Such types of nursery is small and usually established for short duration of time. Temporary nurseries are mostly used for raising seedlings of vegetables and flower crops. Special supervision is not required in the maintenance of such a nursery

\section{Some of the features of this type of nursery are}

- It is constructed for a short period and is small in size.

- Intensive manuring and fertilisation is not necessary in such nursery

- The distance between the nursery and the actual planting site is less.

- No transportation is required, and if any, the cost is less.

\section{Permanent nursery}

In this type of a nursery, the plants are nourished and kept for a longer period of time till they are sold out or planted permanently in a field. Permanent nursery covers a large area than temporary nursery and it covers all the basic features of a permanent nursery. Some of the advantages of permanent nursery are as: 
- More amount of seedlings, grafting stocks are available.

- It is the source of all the planting material

- The initial production cost is reasonable but profits go up in the long run.

\section{On the basis of plants produced}

Ornamental nursery: Ornamental nurseries are meant for growing and conservation of Seedlings, rootstock and ornamental stocks. Various annuals, perennials and rootstocks of ornamentals occupied the flat beds and raised nurseries. A separate block of the nursery consists of vegetative and reproductive phase of bulb and tuber crops. Seedlings of cut and loose flowers, seasonal, bonsai, climbers and creepers are managed individually here.

Vegetable nursery: It accommodates planting of seedlings of vegetables, rooted cuttings (asparagus and sweet potato), rhizomes (ginger), tubers (potato) and bulbs (onion and garlic) where they are raised and conserved.

Fruit nursery: In this nursery, seedlings and rootstocks cuttings, grafts, layers and cuttings of fruit trees, such as mango, lychee, ber, bael, guava, sapota, etc., are raised and conserved for future purpose.

Forest nursery: This type of nursery allows growing of different species offorest trees and climbers planted in 'social forestry', for example plantation along roads, gram panchayat land, gardens. Rootstock of different forest plant species and mother plants are raised in a forest nursery. Seedlings of big trees like Margosa, Gulmohar, Amaltas, Kanchan, Tamarind, Aonla (gooseberry), oak, eucalyptus, etc., are commonly found in a forest nursery.

\section{On the basis of structure used}

Open field nursery: Such type nursery is established in open areas with temporary structure. It consist of raised, or flat sunken seedbeds. These are vulnerable to natural environmental conditions.

Hi-tech nursery: These nurseries are hi cost and needs latest technology. Such a nursery is established under protected structures. The protected structures in which the nursery can be successfully raised are as follows.

Greenhouse or poly-house: It is a covered frame structure covered by poly-film or shade-net which accommodate vegetables and fruits to grow under partially or completely modified environment. The Polyhouses are economical for small and marginal farmers. Good amount of capsicum, cucumber, tomatoes and winter vegetables like tomatoes, cauliflower are reported to produce under protected cultivation of polyhouses (Yadav et al. 2014) ${ }^{\text {[7]. Such }}$ structures are ventilated and may have temperature and humidity controlling devices. The seedlings are raised inside the structure on raised beds or in plug-tray

\section{Management of nursery}

Utmost care and attention are required for nursery plants after they have emerged from the seeds or have been raised from other sources like rootstock or through tissue culture technique. Generally they areprescribe to grow in an open field under natural conditions where, they should be able to face the local environment. Hence seedlings / plants in nursery can be improved by employing best management practices like proper hardening techniques and soil sterilization to enhance the seedling quality (Edralin et al. 2010) ${ }^{[3]}$. Management in the nursery includes all such operations beginning from the emergence of young seedlings till they are fully grown-up or are ready for uprooting and transplanting in the main fields.

\section{Potting the seedling}

Before planting of sapling in the pots, the pots should be filled up with proper potting mixture. It is important to sterilize the potting media to exfoliate themicroorganisms that may damage seeds and seedlings. sterilizationis also done to eliminate the weed seeds which are non-viable thus minimizing weed growth (Edralin et al. 2010) ${ }^{[3]}$. Transplanting of seedlings can be done at two-leaves stage. Some of the expectations are seedlings of $P$. merkusii, Eucalyptus spp., and M. leucadenron. P. merkusii which are transplanted to containers when the cotyledon is still intact with the needles. Only good quality seedlings, which are healthy and germinates normally are transplanted to the container This is the first step of selection of good quality planting materials. For filling of pots loamy soil, sand and compost can be used in 1:1:1 proportion. Sprouted cuttings, bulbs, corms or polythene bag grown plants can be transferred in earthen pots for further growth.

\section{Manuring and irrigation}

Well rotten F.Y.M / compost and leaf mould is added to soil. Rooted cuttings, layers or grafted plants till they are transferred to the permanent location, require fertilizers. Addition of fertilizers will give healthy and vigorous plants with good root and shoot system. It is recommended that each nursery bed of $10 \times 10 \mathrm{~m}$ area should be given $300 \mathrm{gm}$ of ammonium sulphate, $500 \mathrm{gm}$ of Single super phosphate and $100 \mathrm{gm}$ of Muriate of potash.Irrigation either in the nursery beds or watering the pots is an important operation. There should be assured quality of water supply to the nursery plants. use of marginal quality water should be avoided as most of species of fruits sensitive during germination and early seedling stages (Rajkumar. 2016) ${ }^{[7]}$.

\section{Plant protection measures}

Keen observation on attack of different pests and diseases is required. Necessary control measures should be taken immediately on observation. The major horticultural disease of nursery stage plant is "damping off". For its control good sanitation conditions are necessary. Preventive measures like treatment with $50 \%$ ethyl alcohol, $0.2 \%$ calcium hypo chloride and $0.01 \%$ mercury chloride is done. Some of the seed treatments are as follows:

\section{Disinfection}

The infection within the seed is eliminated by use of formaldehyde, hot water or mercuric chloride.

\section{Hot water treatment}

Dry seeds are placed in hot water having a temperature of $48^{\circ} \mathrm{C}-55^{\circ} \mathrm{C}$ for $10-30$ minutes.

\section{Protection}

In dry seed treatment organo mercuric and non-mercuric compounds like agallal, aretan -6 , and tafasan- 6 . For this the seeds are shaken within the seed container. While in wet method, the seeds are immersed for certain period in liquid suspension. 


\section{Soil treatment}

Soil contains harmful fungi, bacteria, nematodes and even weeds seeds, which affect the growth and further development of plant. These can be eliminated by heat, chemical treatment. For that soil is disinfected by heating to the temperature of about $60^{\circ} \mathrm{C}$ for 30 minutes.

\section{Chemical treatment}

The chemicals like formaldehyde, methyl bromide, chloropicrin, vapam are used. Other diseases like rust, powdery mildew, leaf spot, bacterial blight, yellow vein mosaic are also observed. For control of these diseases Bordeaux mixture, Carbendazime, Redomil can be used. Tricodermaviride a bio-fungicide can also be tried out.

\section{Weed control}

Weeds compete with plants for food, space and other essentials, so timely control of weeds is necessary. For weed control weeding, uses of cover crops, mulching and use of chemicals (weedicides) are practiced. Pre-emergence weedicides like basaline or post-emergence weedicide like 2; 4-D and roundup are useful.

\section{Harvesting}

All the seedlings, bulbs, tubers and all the plantlets should be harvested in the proper stage. Only completely ripe seeds are ready for harvesting. This will prevent loss of seeds.Corms and bulbs are generally harvested when the leaves start yellowing or when they dry up. Caring should be taken while dugging out them to avoid any injury. Before harvest, nursery stock should be mature.

\section{Packing of nursery plants}

Packing is the method or way in which the young plants are tied or kept together till they are transplanted. So they have to be packed in such a way that they do not lose their turgidity and are able to establish themselves on the new site. Before packing, the plant produce are allow to dry in shade for 2-3 days and finally in the sun.In husked seeds, the husks are removed before packing. For packing baskets, wooden boxes, plastic bags are used. In some parts of the country banana leaves are also used for packing the plants with their earth ball. This is useful for local transportation. Bulbs, tubers and corms are packed in bamboo-matted boxes in between layers of straw.

\section{Marketing \\ Marketing of nursery plants and planting materials is the most crucial and important part of the nursery business. It is absolutely important in any nursery management to produce high quality true to the type and attractive planting materials. Before marketing it must be ensured that the planting materials should be free from pests and diseases and are vigorously growing, bright and colour. Marketing of good quality produce will ultimately enhance the export value and net return of the business.}

\section{Conclusion}

From the above discussed aspects, it is concluded that for good management of nursery it must be provided with the possible best quality material for planting and development in new areas. Good planting materials will produce higher yield productivity for life span 25 years or more (Singh et al. 2010). All the nursery practices should be performed in a limited dose, it cannot be over-emphasized. Caring of nursery and sharp observation during all the management practices is very essential. Among horticultural crops, the productivity of papaya, banana, grapes and many vegetables is higher in India as compared to rest of the world. So in order to maintain this leadership good quality planting materials should be produced with keen care and efforts. Also to increase the export value of the nursery planting material, it is prime important that all the produced material should be free from disease, pest. Damage or injury during transportation or marketing of the produce should be at minimal. It must be examined carefully during the step. The off-season nursery production was found profitable under polyhouse. Thus the production of off-season fruits and vegetables aids in increasing the income and net returns of the grower, in turn ensure nutritional security to the farmer.

\section{References}

1. Ali M. Influence of seedling age on cucumber (Cucumissativus L.) production. SAARC J. Agri. 2016; 13:214-221.

2. Babaj I, Sallaku G, Balliu A. The effect of plug size and grafting method on the dry matter partitioning and stand establishment rate of grafted cucumber seedlings under saline conditions. Acta Hort. 2012; 960:225-230.

3. Edralin DI, Mercado A. Jr. The need for improved nursery management practices and marketing in tree nurseries of northern Mindanao, 2010. DOI: 10.32945/atr3223a

4. Mavoy G, Ozores-HM. Commercial Transplant Production in Florida. IFAS Extension. 2015; 1:1-12.

5. Nursery establishment and management, Forestry And Environmental Science, Shahajalal University Science Technology, Sylhet Nursery techniques, TNAU Agri. Portal.

6. Oagile O, Gabolemogwe P, Matsuane C. Effect of container size on the growth and development of tomato seedlings. Int. J. Curr. Microbiol. App. Sci. 2016; 5:890896.

7. Rajkumar, Singh, Anshuman, Yadav RK. Nursery management in fruit crops in salt-affected soils. In: Quality seed production, processing and certification of selected field and vegetable crops in salt affected areas. Training Manual, ICARCSSRI, Karnal, India, 2016, 125$131 \mathrm{p}$.

8. Sallaku G, Bani A, Balliu A. The effects of $N$ concentration in pre-transplant nutrient solution on the $\mathrm{N}$ use efficiency and dry mass partitioning of vegetable solanaceae seedlings. Acta Hort. 2009; 830:405-412.

9. Singh RR, Meena LK, Singh Paramveer. Int. J. Curr. Microbiol. App. Sci. 2017; 6(6):3162-3172

10. Tripathi PC. Principal Scientist and Head, Nursery Management in horticultural crops - compendium, CHES, Chettalli - 571248. 